\title{
Pelatihan Proses Pasteurisasi Sebagai Upaya Menumbuhkan Kemandirian Pemasaran Susu Kambing di Kelompok Sukorejo I, Turi, Sleman
}

\author{
Y. Suranindyah, F. T. Haryadi, D.T. Widayati \\ Fakultas Peternakan Universitas Gadjah Mada, Jl. Fauna No 3 Bulaksumur, Yogyakarta \\ Email: yuni.suranindyah@ugm.ac.id \\ https://doi.org/10.24071/altruis.2018.010108
}

\begin{abstract}
Abstrak
The activities of community service which were conducted in Sukorejo, Girikerto, Turi, Sleman aimed to train farmers to be able to produce high quality goat milk, be skillful to process pasteurized milk, and be capable of marketing their dairy products. The activities consisted of counseling and training, focusing on the implementation of hygienic milking procedure and processing pasteurized milk. The community service was carried out in partnership with Plaza Agro, the Faculty of Animal Husbandry of Universitas Gadjah Mada, which is engaged in the sale of dairy and agricultural products. The training materials consisted of lactating goats, stage pens, goat milk, pasteurization and packaging equipment, and chemicals for milk quality testing. Counseling and discussion were done either during farmers meeting or between their activities in the communal goat houses. The program also carried out the procurement of equipment for milk processing and packaging which was facilitated by IbM Ristek Dikti (Higher Education) program 2016. Training results showed that an increase in the number of farmers who implemented hygienic milking, especially on the sanitation aspect, resulting in good quality milk. Density ranged from 1.030 to 1.034 in gravity, 5.5 to $5.6 \%$ of fat content and 15.3 to $15.5 \%$ of dry matter. The mild had a good flavor, odorless, and without alcohol. The quality of pasteurized milk was good, odorless, and had a typical goat's milk flavor. The reduction time of metylene blue reduction test was 7.9 hours, indicated that the approximate number of bacteria in milk approached $150000 / \mathrm{mL}$, whose average of shelf life was 7 days. Initial marketing of pasteurized goat milk in Plaza Agro was limited on a small scale. The study concluded that processing pasteurized milk was useful for farmers to find an alternative market of goat milk.
\end{abstract}

Keywords: kelompok peternak, pemasaran susu, susu kambing pasteurisasi

\section{PENDAHULUAN}

Susu kambing memiliki keunggulan dari segi nutrisi, yaitu tinggi kandungan protein, lemak dan vitamin A, serta mudah dicerna karena butir lemaknya berukuran kecil (Park, 2010). Susu kambing juga diketahui sebagai sumber potassium, yaitu mineral yang berperan menjaga tekanan darah dan fungsi jantung (Getaneh et al., 2016). Asam lemak rantai pendek dan rantai sedang, yaitu asam Caproic, Caprylic dan Capric dalam susu kambing merupakan sumber energi yang baik dan mudah diserap oleh darah (Kompan dan Komprej, 2016). Oleh karena itu untuk mempertahankan nutrien dan manfaat susu kambing tersebut diperlukan penanganan, dan pengolahan yang baik.

Sebagian besar susu kambing yang beredar di masyarakat dihasilkan oleh peternak kambing Peranakan Etawah (PE). Desa Girikerto, Turi, Sleman merupakan salah satu wilayah produksi susu kambing. Populasi kambing PE di kabupaten Sleman pada tahun 2015 sebanyak 36.586 ekor (BPS, 2017). Pemilikan kambing 1 sampai 10 ekor/peternak dan produksi susu sekitar 1 sampai 5 liter/peternak/hari (Seftiarini, 2011).Permasalahan yang dihadapi oleh peternak kambing perah adalah keterbatasan dalam pemasaran susu. Sampai saat ini susu kambing yang dihasilkan oleh peternak di sekitar Girikerto dipasarkan sebagai bahan baku susu kering. Jumlah pengolah susu kambing kering di desa Girikerto ada 9 pengusaha. Harga dan kuantitas susu kambing segar yang dapat dibeli tergantung pada pengolahan susu kering. Sering terjadi susu tidak terserap karena pemasaran susu kering terhambat. Kondisi tersebut mengakibatkan peternak berhenti memerah kambingnya, sehingga beresiko menyebabkan mastitis. Untuk mengatasi keterbatasan pasar tersebut, diperlukan pemasaran susu dalam bentuk lain sebagai alternative, agar peternak tidak tergantung pada satu pihak. Salah satu cara tersebut adalah dengan membuat produk olahan. Susu kambing dapat diolah menjadi berbagai produk, 
seperti susu pasteurisasi, yoghurt, keju, tahu susu, dodol atau caramel.

Di antara beberapa teknologi pengolahan susu, pasteurisasi paling luas diadopsi untuk menjadikan susu aman dikonsumsi manusia (Sarkar, 2015). Temperatur dan waktu yang diterapkan pada pasteurisasi terdiri dari temperatur minimal $62,8^{\circ} \mathrm{C}$ selama 30 menit atau $72,8^{\circ} \mathrm{C}$ minimal selama 16 detik dan $80^{\circ} \mathrm{C}$ tanpa batasan waktu holding time (Lavigne et al., 1989). Tujuan dari proses pasteurisasi adalah menghancurkan bakteri dalam susu yang mungkin masuk saat pemerahan dan yang menyebabkan penyakit. Pasteurisasi mematikan bakteri patogen, yeast, jamur dan berpengaruh kecil terhadap vitamin yang secara alami terdapat dalam susu (Brown, 2015). Temperatur pasteurisasi berpengaruhi terhadap bakteri yang bertahan dalam susu (Dumalisile et al, 2005). Ditinjau dari aspek nutrien, pasteurisasi merupakan proses pengolahan yang mampu mempertahankan keutuhan komponen susu, sehingga sesuai untuk susu kambing untuk mendapatkan manfaat dari nilai nutrisinya. Di samping itu susu pasteurisasi juga diminati masyarakat. Hasil penelitian Hartono et al. (2010) $82 \%$ pembeli susu pasteurisasi adalah individu dan $12 \%$ individu dan kelompok, misalnya kegiatan sekolah dan organisasi. Oleh karena itu kegiatan pengabdian masyarakat di kelompok peternak ini memilih pasteurisasi sebagai pengolahan susu kambing, dengan tujuan meningkatkan pemasaran susu yang dihasilkan oleh peternak.

\section{METODE}

Kegiatan pengabdian masyarakat berlangsung dari bulan April sampai dengan November 2016 di kelompok peternak Sukorejo I, Girikerto, Turi, Sleman. Materi yang digunakan terdiri dari kambing PE laktasi, kandang dan peralatannya, susu kambing, peralatan pasteurisasi dan pengemasan (sealer, gelas dan plastik kemasan susu) serta alat penyimpanan susu (cooler box, refrigerator dan freezer), bahan baku untuk pengolahan susu pasteurisasi (gula, perisa dan pewarna makanan) dan bahan pengujian kualitas susu. Kegiatan pengabdian terdiri dari tahap persiapan, pelaksanaan dan evaluasi. Kegiatan pada tahap persiapan berupa diskusi dan observasi untuk mendapatkan data kondisi awal dan permasalahan yang dihadapi kelompok peternak yang berkaitan dengan produksi susu kambing.

Tahap pelaksanaan terdiri dari penyuluhan dan pelatihan, pengumpulan susu dan merintis pemasaran produk susu pasteurisasi dengan mitra kerja. Materi penyuluhan terdiri dari proses pemerahan higienis, pengujian kualitas susu secara sederhana, penanganan susu pasca pmenerahan, pasteurisasi susu dan pemasaran produk olahan. Penyuluhan dilakukan pada pertemuan kelompok maupun secara langsung pada saat peternak melakukan kegiatan di kandang kelompok. Pelatihan terdiri dari praktek pemerahan higienis, menguji kualitas susu secara sederhana, pengolahan susu pasteurisasi dan pengemasan produk. Dalam kegiatan diskusi dan penyuluhan jumlah peternak yang berpartisipasi antara 25 sampai 31 orang sedangkan pelatihan hanya diikuti oleh ibu-ibu dan peternak yang menghasilkan susu kambing, berjumlah 11 orang. Selama pelatihan diamati dilakukan pengamatan terhadap peternak dalam penerapan proses pemerahan dihigienis, pengujian kualitas susu yang dihasilkan (uji berat jenis, kadar lemak, total bahan kering, uji alkohol, dan sensoris, yaitu bau dan rasa). Kemampuan peternak dalam proses pasteurisasi dinilai dari kualitas susu yang dihasilkan (kebersihan, bau, rasa, jumlah bekteri dan daya simpan). Pada kegiatan ini dilakukan pengadaan peralatan dan bahan untuk mendukung kegiatan yang pendanaannya berasal dari Program IbM Ristek Dikti tahun 2016. Mitra kerja pemasaran dalam kegiatan ini adalah Plasa Agro Fakultas Peternakan UGM yang bergerak dalam bidang penjualan produk peternakan dan pertanian. Selama kegiatan pelatihan berlangsung, mitra kerja membantu memasarkan produk susu pasteurisasi.

Tahap evaluasi dilakukan pada akhir kegiatan. Pada tahap ini dilakukan analisis data yang dikoleksi selama pengabdian masyarakat untuk mengetahui dampak kegiatan terhadap aktivitas peternak di kelompok. Evaluasi ditinjau dari aspek aktivitas peternak, kualitas susu yang dihasilkan, dan pemasaran susu, serta kegiatan lain di kelompok. Bagian ini merupakan bagian utama artikel hasil pengabdian kepada masyarakat dan biasanya merupakan bagian terpanjang dari suatu artikel. Hasil pengabdian kepada masyarakat yang disajikan dalam bagian ini adalah hasil "bersih". Tabel dan grafik dapat digunakan untuk memperjelas penyajian hasil pengabdian kepada masyarakat secara verbal. Tabel dan grafik harus diberi komentar atau dibahas.

\section{HASIL DAN PEMBAHASAN}

\section{Kondisi awal kelompok}

Dari pengamatan awal diperoleh data jumlah anggota kelompok Sukorejo I sebanyak 34 orang, populasi kambing PE keseluruhan 400 ekor, terdiri dari 200 ekor betina, 18 pejantan, 182 kambing muda dan anak kambing. Jumlah kambing yang diperah 49 ekor (12\% dari populasi). Pemeliharaan kambing PE berlangsung di lokasi kandang kelompok, menempati tanah yang disewa dari kas desa seluas 3 Ha. Lokasi kandang berbentuk perkampungan ternak, terdiri dari 42 kandang. Tiap peternak memiliki 1 sampai 2 kandang dengan pemilikan kambing antara 2 sampai 20 ekor. Kelompok melakukan pertemuan rutin setiap awal bulan. 
Kambing PE di kelompok Sukorejo I dikembangkan untuk menghasilkan susu, anak kambing dan pupuk organik. Produksi susu berkisar antara 13 sampai 20 liter/hari. Jumlah peternak yang melakukan pemerahan sebanyak 11 orang.Permasalahan yang dihadapi kelompok yang utama adalah keterbatasan pemasaran susu karena selama ini susu kambing segar hanya dijual ke produsen susu kering. Kuantitas dan harga susu dari peternak berfluktuasi, tergantung pada penjualan susu kering.

Hasil pengamatan di kandang kelompok menunjukkan bahwa pemeliharaan kambing berjalan dengan baik, menggunakan kandang tipe panggung, pakan yang diberikan terdiri dari hijauan (rumput, dan leguminosa) dan konsentrat. Proses pemerahan dan penanganan susu masih perlu diperbaiki karena kurang higienis.Peternak secara individu maupun kelompok tidak melakukan pengolahan susu.

\section{Hasil pengabdian masyarakat}

Penyuluhan dan pelatihan meningkatan jumlah peternak yang menerapkan produksi susu kambing higienis sebagai proses pra produksi susu pasteurisasi. Penyuluhan dan pelatihan bermanfaat untuk meningkatkan pengetahuan peternak mengenai pentingnya sanitasi lingkungan, ternak dan peralatan pemerahan serta proses pemerahan yang benar dan higienis untuk menghasilkan susu kambing yang sehat. Setelah pelatihan peternak yang melakukan pengeringan ambing setelah ambing dicuci dan membuang susu pancaran pertama sebelum hasil perahan ditampung jumlahnya lebih banyak dibanding pada kondisi awal (Tabel 1). Faktor kebersihan ambing ini mendapatkan perhatian yang penting karena mempengaruhi kebersihan dan jumlah bakteri dalam susu.Peningkatan sanitasi tersebut diharapkan berdampak baik terhadap kualitas susu yang dihasilkan, karena tidak ada sisa air pencuci ambing yang masuk ke dalam susu dan susu yang tertampung bebas dari kotoran serta bakteri yang terdapat pada putting. Menurut Murphy dan Boor (2010) pembersihan putting dengan larutan sanitasi diikuti dengan pengeringan menggunakan kain yang bersih sebelum pemerahan dapat mengurangi jumlah mikroorganisme dalam susu. Verdier-Metz (2011) mensitasi dari Gill et al. (2006) dan Rendos et al. (1975) mikroorganisme masuk ke dalam susu setelah susu melewati lubang putting, karena adanya kontak dengan permukaan kulit pada permukaan putting susu, kontaminasi udara dan lingkungan sekitar ternak. Saluran, ujung, dan lubang puting susu pada ternak perah dapat menjadi tempat berkembangnya berbagai macam bakteri, termasuk bakteri patogen. Peternak anggota kelompok sudah melakukan pemerahan secara rutin dan apuh sejak awal.

Dalam kegiatan ini untuk mempertahankan kualitas susu yang terkumpul di kelompok, maka peternak yang boleh menyetor ke kelompok dibatasi hanya mereka yang mau mengikuti aturan pemerahan higienis dan menggunakan penampung susu yang bersih. Menurut Bahri et al. (2005) proses praproduksi berperan penting dalam menghasilkan produk ternak yang aman dan bermutu untuk konsumsi manusia. Faktor lingkungan (tanah, air, udara) di mana ternak dipelihara dapat mempengaruhi keamanan ternak dan produk yang dihasilkan.Dalam kegiatan pengabdian masyarakat ini pemerahan higienis merupakan inovasi yang dikenalkan pada kelompok untuk meningkatkan kualitas pra produksi pasteurisasisusu. Jumlah peternak yang menerapkan pemerahan higienis meningkat karena inovasi mudah dipraktekkan dan bermanfaat langsung pada kesehatan ternak maupun susu yang dihasilkan.

Tabel 1. Jumlah peternak yang melaksanakan prosedur pemerahan higienis sebelum dan setelah pelatihan $(n=11)$

Tahap pemerahan higienis yang diterapkan Jumlah peternak (orang)

\begin{tabular}{lcc}
\hline \multicolumn{1}{c}{ Tahap pemerahan higienis yang diterapkan } & \multicolumn{2}{c}{ Jumlah peternak (orang) } \\
\cline { 2 - 3 } Sebelum Pemerahan & Sebelum & Setelah \\
melakukan sanitasi kandang, ternak, peralatan & 11 & 11 \\
mencuci tangan & 11 & 11 \\
mencuci ambing ternak & 0 & 11 \\
mengeringkan ambing dengan kain bersih setelah & 4 & 5 \\
pencucian ambing & & 11 \\
membuang susu pancaran pertama & 9 & 11 \\
Pelaksanaan Pemerahan & 2 & 7 \\
pemerahan apuh dan rutin & & 11 \\
menggunakan penampung susu bersih dan sehat & 8 & 11 \\
Penanganan Susu Paska Pemerahan & 11 & \\
menyaring susu hasil perahan & & \\
menyimpan susu di suhu $4^{\circ} \mathrm{C}$ & & \\
\hline
\end{tabular}


Sebelum dan setelah kegiatan pengabdian masyarakat komposisi susu kambing tidak menunjukkan perbedaan nyata. Berat jenis susu1,030 - 1,034;kadar lemak 5,5 $5,6 \%$ dan total bahan kering $15,3-15,5 \%$.

Tabel 2. Jumlah peternak yang menghasilkan susu berkualitas baik sebelum dan setelah pelatihan $(n=11)$

\begin{tabular}{lcc}
\hline \multicolumn{1}{c}{ Kualitas susu kambing } & \multicolumn{2}{c}{ Jumlah peternak (orang) } \\
\cline { 2 - 3 } & Sebelum & Setelah \\
\hline Warna susu normal (putih) & 11 & 11 \\
Susu bersih (tidak tercampur kotoran) & 8 & 11 \\
Bau susu normal (tidak prengus) & 2 & 0 \\
Uji alkohol negative & 11 & 11 \\
\hline
\end{tabular}

Berdasarkan komposisinya maka susu kambing yang dihasilkan kelompok peternak pada kegiatan pengabdian masyarakat ini memenuhi standard, yaitu bahan kering dan kadar lemak minimal13,0 dan 4\%(Thai Agricultural Standard, 2008).

Jumlah peternak yang menghasilkan susu berkualitas baik (bersih dan tidak berbau prengus) mengalami peningkatan setelah pelatihan. Tujuan kegiatan yaitu menghasilkan susu kambing berkualitas di kelompok peternak tercapai antara lain dengan adanya percontohan dari peternak sendiri. Selama pelatihan dilakukan pengambilan foto dan rekaman peternak yang mampu mengerjakan proses pemerahan higienis dengan baik sebagai contoh yang benar. Sebaliknya juga dilakukan pada peternak yang masih kurang bersih dalam melakukan pemerahan, untuk dijadikan contoh yang masih perlu diperbaiki. Pada pertemuan kelompok hasil rekaman tersebut ditampilkan sebagai bahan diskusi. Dengan cara tersebut masing-masing peternak dapat mengoreksi dan memperbaiki kegiatan yang dilakukan. Peningkatan kemampuan peternak dalam memproduksi susu higienis juga didukung dengan penyediaan peralatan, misalnya botol penampung susu yang mudah dibersihkan, kain pengering, penyaring susu, dan pendingin (refrigerator) untuk penyimpanan susu. Di samping kualitas susu meningkat, peternak juga mampu membedakan susu kambing yang baik dan buruk atau rusak secara sederhana dan menghindari bau prengus pada susu

Pelatihan pasteurisasi susu. Pelatihan dilakukan seminggu sekali dan berlangsung 10 kali. Bahan utama berupa susu kambing segar diperoleh dari hasil pemerahan kambing peternak setiap pagi dengan cara dikumpulkan di pos pertemuan kelompok. Volume susu yang terkumpul berkisar antara 3 sampai 10 liter. Bahan yang ditambahkan terdiri dari gula, perisa dan pewarna makanan. Susu diolah dengan panci ganda dan pasteurizer skala 10 liter dengan pemanasan sampai suhu $80^{\circ} \mathrm{C}$ kemudian didiamkan selama 30 detik dan segera didinginkan. Setelah dingin susu pasteurisasi dikemas dalam gelas dan ditutup dengan plastik penutup menggunakan cup sealer.

Susu pasteurisasi hasil pengolahan diuji rasa, bau, dan daya simpan sebelum mulai dipasarkan pada mitra kerja. Hasil uji rasa dan bau oleh panelis terhadap 5 sampel pengolahan menunjukkan skor rata-rata 1,48 $\pm 0,46$. Skor 1 untuk rasa dan bau tidak prengus, skor 2 ada rasa dan bau prengus. Hasil uji Uji chi square berbeda nyata ( $\mathrm{P}<$ $0,05)$, sehingga dapat dinyatakan susu hasil pasteurisasi ada rasa prengus. Lama simpan tercatat 4 sampai 7 hari. Pengolahan tahap kedua dilakukan sampai dicapai hasil yang baik, yaitu bersih, bau tidak prengus, flavor susu khas kambing masih terasa. Hasil pengujian metylene blue reduction test (MBRT) pada sampel susu hasil pelatihan tahap kedua menunjukkan waktu reduksi 7,9 jam. Berdasarkan waktu reduktase tersebut, jumlah bakteri dalam susu pasteurisasi diperkirakan mendekati 150.000/mL. Muhammad et al. (2009) jumlah bakteri susu dengan waktu reduksi lebih dari 8 jam antara 100.000 sampai $150.000 / \mathrm{mL}$. Jumlah bakteri dalam susu kambing pasteurisasi menurut Cupáková et al. (2012) mencapai 569.400/mL. Hasil pasteurisasi dalam kegiatan ini menunjukkan jumlah bakteri yang lebih rendah dari hasil penelitian serupa pada susu kambing, oleh karena itu dapat dinyatakan kualitas kebersihan yang dicapai sudah baik. Meskipun demikian daya simpan pada suhu 4 ${ }^{\circ} \mathrm{C}$ terbatas 7 hari. Hasil penelitian Petrus et al. (2010) pada susu pasteurisasi yang disimpan dalam suhu 2, 4, 9, 14 dan $16{ }^{\circ} \mathrm{C}$ mencapai waktu simpan masing-masing 43, 36, 8, 5 dan 3 hari. Kristanti (2017) dengan pemanasan $95^{\circ} \mathrm{C}$ selama 21 detik, mencapai lama simpan 30 hari pada suhu $4{ }^{\circ} \mathrm{C}$, sedangkan dengan metode high temperature short time (HTST) menurut Herawati (2008) mencapai 2 minggu.

Pendeknya masa simpan susu pasteurisasi dalam kegiatan ini disebabkan kondisi lingkungan dan peralatan yang masih kurang memadai. Menurut Sarkar (2015) kualitas susu pasteurisasi dipengaruhi oleh jumlah dan jenis mikroorganisme dalam susu, suhu pemanasan dan waktu pasteurisasi, jumlah mirkoorganisme dalam susu segar dan kondisi proses dan kontaminasi setelah pasteurisasi. 
Oleh karena itu sanitasi selama proses pengolahan perlu ditingkatkan. Pada kegiatan ini untuk menjaga keberlanjutan disepakati ada 3 orang ibu yang bertanggung jawab terhadap pengolahan susu sampai pada pemasarannya.

Selain bermanfaat bagi ketrampilan ibu-ibu, pelatihan pengolahan susu ini berdampak baik pada proses pemerahan dan memotivasi peternak memproduksi susu berkualitas dan bersih. Di samping itu kegiatan pengumpulan susu ke kelompok menjadi aktif kembali.

Pemasaran susu pasteurisasi. Susu pasteurisasi yang dihasilkan diberi label "MILKAPI" singkatan dari "Milk Kambing Lereng Merapi", dikemas dalam gelas plastik, volume $120 \mathrm{ml}$ dengan variasi rasa coklat, dan strawberry, harga Rp 4.000/kemasan. Kemasarn lain berupa susu tanpa rasa (tawar) dengan kemasan kantong plastik volume $250 \mathrm{ml}$, harga Rp.7.000/kemasan. Pemasaran susu dirintis melalui Plasa Agro Fakultas Peternakan UGM. Pada awal pemasaran dijumpai beberapa permasalahan karena harga susu lebih mahal hampir 3 kali dibanding susu sapi, konsumen masih mempunyai kesan goaty flavor (bau prengus) terhadap susu kambing, sehingga minat membeli rendah. Meskipun demikian perintisan pemasaran tetap berjalan dalam skala kecil (5 liter/minggu). Hasil pengamatan menunjukkan bahwa susu tanpa rasa (tawar) lebih disukai oleh konsumen, sehingga untuk selanjutnya susu pasteurisasi diproduksi tanpa rasa.

Susu pasteurisasi memberikan nilai tambah dibandingkan dengan penjualan dalam bentuk beku ke pengolah susu bubuk. Harga jual ke pengolah susu bubuk maksimum Rp. 15.000/liter, sedangkan dalam bentuk susu pasteurisasi menjadi Rp. 28.000/liter. Keuntungan lain dari proses pasteurisasi adalah nilai nutrisi susu kambing dapat dipertahankan dalam waktu yang lebih lama, sehingga memberikan manfaat kesehatan bagi masyarakat. Bagi kelompok peternak kegiatan ini memberikan tambahan pendapatan, membangun kegiatan pengumpulan susu, dan memberikan semangat bagi peternak untuk memproduksi susu kambing. Keberlanjutan kegiatan ini masih diperlukan oleh peternak dalam bentuk pendampingan pemasaran susu agar menjadi usaha yang memberikan keuntungan ekonomi secara nyata.

\section{KESIMPULAN DAN SARAN}

\section{Kesimpulan}

Kegiatan pengabdian masyarakat di kelompok Sukorejo I dalam bentuk penyuluhan dan pelatihan berhasil meningkatkan jumlah peternak yang mampu menerapkan pemerahan higienis untuk menghasilkan susu kambing yang berkualitas. Susu pasteurisasi hasil pelatihan mencapai kualitas baik tetapi perlu ditingkatkan sanitasinya karena memiliki daya simpan pendek. Susu kambing pasteurisasi dapat dipasarkan melalui mitra kerja tetapi masih terbatas dalam skala kecil. Kesan kurang baik terhadap rasa susu kambing dan harga yang lebih mahal menjadi penghambat pemasaran susu kambing pasteurisasi.

\section{Saran}

Diperlukan monitoring dan kegiatan lanjut unruk pendampingan pemasaran produk yang sudah dihasilkan oleh kelompok peternak.

\section{UCAPAN TERIMA KASIH}

Terima kasih kepada Pengelola Program IbM Ristek Dikti tahun 2016 atas pendanaan untuk pelaksanaan kegiatan Pengabdian masyarakat ini.

\section{DAFTAR PUSTAKA}

Bahri, S., E. Masbulan dan A. Kusumaningsih. 2005. Proses praproduksi sebagai faktor penting dalam menghasilkan produk ternak yang aman untuk manusia. Jurnal Litbang Pertanian, 24 (1):27

BPS. 2017.https://yogyakarta.bps.go.id/linkTabelStatis/ view/id/53

Brown, A.C. 2011. Understanding Food: Principles and Preparation, $4^{\text {th }}$ ed., Cengage Learning.

Cupáková, S., M. Pospíšilová, R. Karpíšková, B. Janštová, L. Vorlová. 2012. Microbiological quality and safety of goat's milk from one farm. Acta Universitatis Agriculturae et Silviculture Mendelianae Brunensis. Vol 4 (6): 33-38.

Dumasilisile, P., R. C. Witthuhn and T. J. Britz. 2005. Impact of different pasteurization temperatures on the survival of microbial contaminants isolated from pasteurized milk. DOI: 10.1111/j.14710307.2005.00189.x

Getaneh G., A. Mebrat, A. Wubie, H. Kendie. 2016. Review on Goat Milk Composition and Its Nutritive Value. J Nutr Health Sci 3(4): 401

Hartono, B., H. D. Utami, dan N. Amanatullaili. 2010. Analisis faktor-faktor yang mempengaruhi konsumen dalam membeli produk susu pasteurisasi kabupaten Kudus. Buletin Peternakan Vol. 34(2): 123-130

Herawati, H. 2008. Penentuan umur simpan pada produk pangan. Jurnal Litbang Pertanian, 27(4), 2008 124130

Kompan, D. and A. Komprej. 2016. The Effect of Fatty Acids in Goat Milk on Health. Available on http://dx.doi.org/10.5772/50769

Kristanti, N. D, 2017. Daya simpan susu pasteurisasi ditinjau dari kualitas mikrobia termodurik dan kualitas kimia. Jurnal Ilmu dan Teknologi Hasil Ternak, Vol. 12 (1): 1-7

Lavigne, I., C., J. A. Zee. R. E. Simard, B. Béliveau, 1989. Effect of Processing and Storage Conditions on the Fate of vitamins $\mathrm{B}_{1}, \mathrm{~B}_{2}$, and $\mathrm{C}$ and on the 
Shelf-Life of Goat's Milk. DOI: 10.1111/j.1365621.1989.tb08560.x

Muhammad K., Altaf I., Hanif A., Anjum A. A., and Tipu M. Y. 2009. Monitoring hygienic status of raw milk marketed in Lahor city Pakistan. The Journal of Animal \& Plant Sciences 19(2): 74-77

Murphy, S. C. and K. J. Boor. 2010. Sources and Causes of High Bacteria Counts in Raw Milk: An Abbreviated Review.

http://articles.extension.org/pages/11811/sourcesand-causes-of-high-bacteria-counts-in-raw-milk:an-abbreviated-review, diakses 8 Desember 2017

Park Y. W. 2010. Goat Milk Products: Quality, Composition, Processing, Marketing In: W.G. Pond $\&$ N. Bell (Eds). Encyclopedia of Animal Science. 2nd Edition. Taylor and Francis. CRC Press. Boca Raton, FL

Petrus, R. R., C. G. Loiola, C. A. Oliveira. 2010. Microbilogical shelf life of pasteurized milk in bottle and pouch. J. Food Csi. 75 (1): 36-40. doi: 10.1111/j.1750-3841.2009.01443.x.

Sarkar, R. 2015. Microbiological Considerations: Pasteurized Milk. International Journal of Dairy Science 10 (5): 206-218

Seftiarini, N. 2011. Studi Komparasi Pengelolaan Peternakan Kambing Peranakan Etawa (PE) di Dususn Nganggring dan Dususn Kebonan di Kabupaten Sleman. Skripsi. Universitas Negeri Yogyakarta

Thai Agricultural Standard. 2008. Raw Goat Milk. National Bureau of Agricultural Community and Food Standard Ministry of Agriculture and Cooperatives, Chatuchak, Bangkok p2

Verdier-Metz, I., G. Gagne, S.Monsallier, P. Veisseire, C.Delbès-Paus. 2011. Cow Teat Skin, a Potensial Source of Diverse Microbial Population for Cheese Production. Applied and Environmental Microbiology 78(2):326-333 